\title{
Women in crime
}

\section{Over the last 50 years women have been increasing their participation in the labor market and in the crime market}

Keywords: crime, women, gender gaps

\section{ELEVATOR PITCH}

In recent decades, women's participation in the labor market has increased considerably in most countries and is converging toward the participation rate of men. Though on a lesser scale, a similar movement toward gender convergence seems to be occurring in the criminal world, though many more men than women still engage in criminal activity. Technological progress and social norms have freed women from the home, increasing their participation in both the labor and the crime market. With crime no longer just men's business, it is important to investigate female criminal behavior to determine whether the policy prescriptions to reduce crime should differ for women.

\section{KEY FINDINGS}

\section{Pros}

( More women are committing crimes than in the past, but they have not yet caught up with men.

๑ The gender gap in crime is partly explained by women's lower criminal earnings and lower responsiveness to changes in expected criminal earnings.

๑ Since having young children reduces a woman's propensity to commit crimes, subsidies for having children might reduce female criminality.

๑ Married women are more likely to have children and to be able to insure against negative income shocks through their husbands' incomes, thus reducing their propensity to commit crime.

๑ Reducing wage disparities across female skilled and unskilled workers might decrease the inclination of women to commit crimes.
Female prisoners in industrial countries

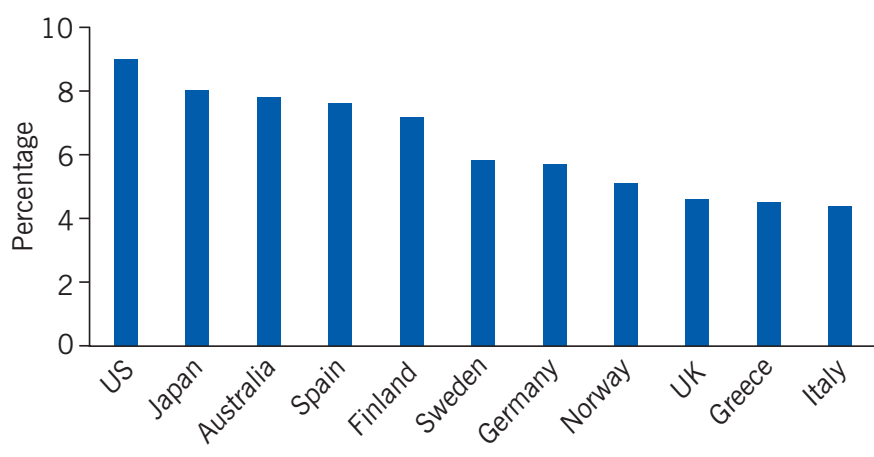

Source: International Centre for Prison Studies. Online at: http://www. prisonstudies.org

\section{Cons}

- Traditional policies to fight crime have not distinguished between women and men, as not enough is known about what motivates female criminals.

- Technological progress and social norms have freed women from the home, increasing their participation in both the labor market and the crime market.

- A higher participation of women in the labor market might increase female participation in the crime market.

- Convergence in the social roles of women and men might increase crimes committed by women.

- The judicial system seems to be more lenient toward female offenders.

\section{AUTHOR'S MAIN MESSAGE}

There is still a gender gap in the crime market, but the number of women committing crimes is on the rise, partly because other socio-economic gender gaps have been shrinking. Women have more freedom than in the past, and with that come more opportunities for crime. Despite increasing social equality, police and judicial systems still tend to be more lenient with female than with male offenders. Policies to reduce wage disparities between skilled and unskilled female workers, such as incentivizing female education, might reduce crime among disadvantaged women. Family support policies, by encouraging marriage and having children, might also reduce crime among women. 


\section{MOTIVATION}

It is known that most criminals are male and that the share of female criminals is rising. But not enough is known about trends in the gender gap and the reasons behind gender differences in criminal behavior. Prevention, punitive, and rehabilitation policies have failed to distinguish between women and men. The economic literature, which has extensively explored gender convergence in the labor force, has under-investigated the issue of female participation in the crime market. Analyzing the gender gap in the crime market and its evolution and identifying its main determinants are important for effectively fighting crime. It is crucial to learn whether men and women behave differently in the crime market and, if so, to uncover the main drivers of these differences and to set policy incentives accordingly.

If the participation gap in the crime market is driven by social roles, as some hypothesize, the number of women committing crimes should rise as women spend more time outside the home. On the other hand, it can be argued that the number of female criminals should decline (at least for property crimes, such as larceny, fraud, and embezzlement) if women have more and better opportunities in the legal labor market. Which force prevails is a matter for empirical analysis.

\section{DISCUSSION OF PROS AND CONS}

\section{Female crime and female participation in the labor market}

Over the last 80 years in the US, labor force participation by women has been increasing almost continuously, doubling from around 22\% in 1930 to $45 \%$ in 2009 (Figure 1).

Figure 1. Fraction of women incarcerated and in the labor force in the US

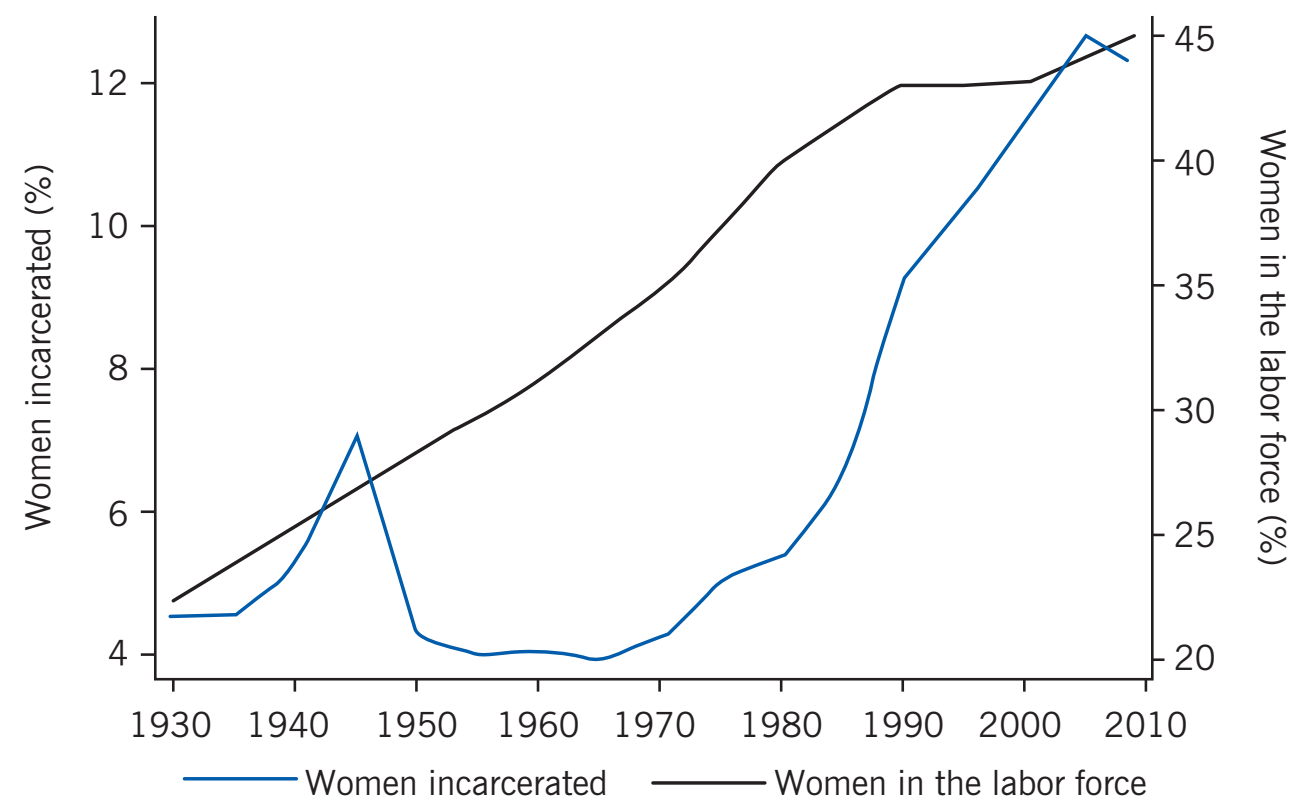

Source: Data on incarcerated women: National Archive of Criminal Justice Data. Online at: https://www.icpsr.umich. edu/icpsrweb/NACJD; US Census Bureau. Online at: https://www.census.gov/compendia/statab/2011/cats/law_ enforcement_courts_prisons.html; Data on women in the labor force: Blau, F. D., M. A. Ferber, and A. E. Winkler. The Economics of Women, Men, and Work. 4th edition. Upper Saddle River,NJ: Prentice Hall, 2002; World Bank. Online at: https://www.worldbank.org 
Apart from the post-Second World War drop that was driven by the absence of so many prime-age men during the war, the percentage of arrestees that are female has shown a similar trend, especially over the last 50 years. More recently, however, this growth seems to show some signs of leveling off.

To date, economic studies of female criminal behavior have used US data, which raises the question of whether trends in the gender participation gap in crime are a global phenomenon or specific to the US. Analysis for this article of UN survey data on crime trends for six countries with adequate data between 1980 and 2006 shows that the crime participation gap is common to many countries, and that just as in the US, the trend in female crime in these countries has been rising (Figure 2).

Figure 2. Female convictions have been rising in several countries

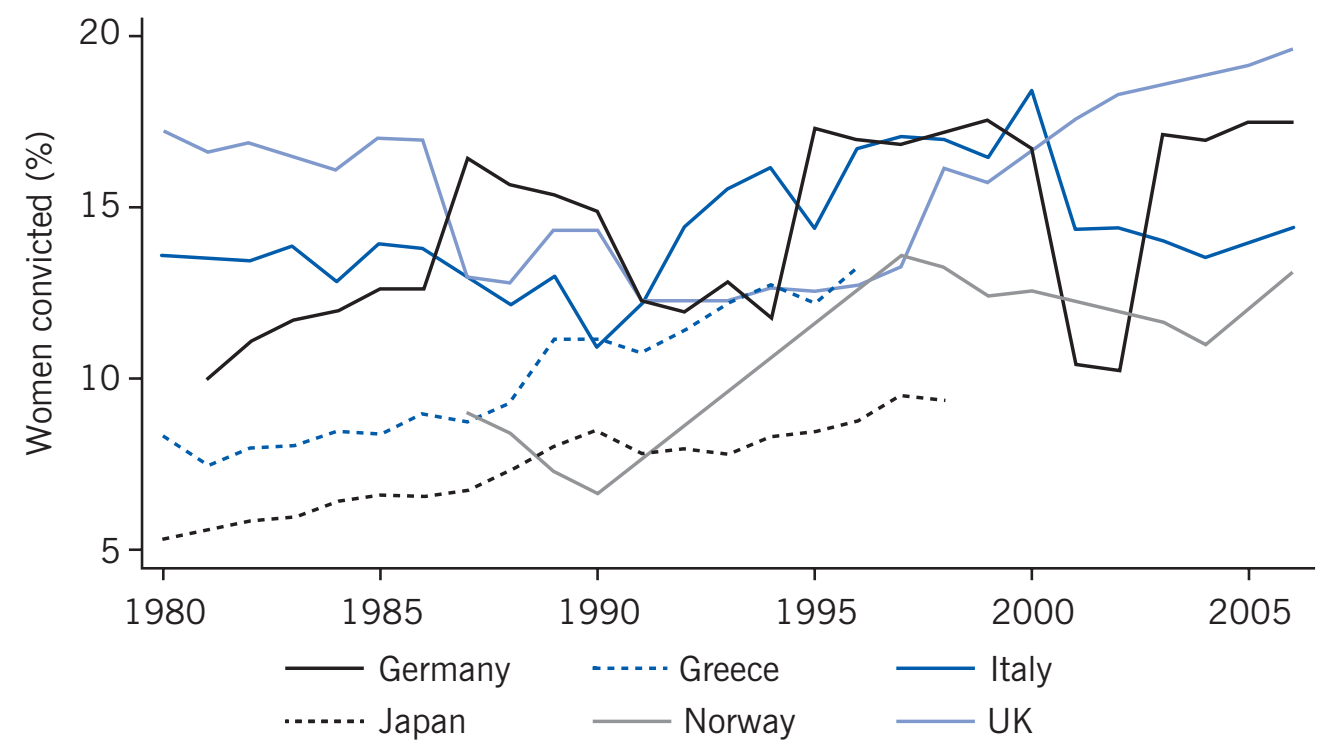

Source: United Nations, "Surveys of crime trends and operations of criminal justice systems series." Online at: http://www.icpsr.umich.edu/icpsrweb/NACJD/series/00186

\section{Why do women commit crimes?}

Economists entered the discussion on criminal behavior with a pioneering 1968 study that looks at criminals as rational actors who decide to commit a crime if the expected benefits are higher than the expected costs [1]. In other words, when all the other variables are held constant, a change in the incentives to engage in criminal activities leads to an increase (or a decrease) in the number of crimes committed. The decision to commit a crime depends, among other things, on the probability of being caught and the probable length and severity of the sentence if the perpetrator is caught; the disutility of going to jail; the expected earnings from the illegal activity; work opportunities in the legal labor market; and risk aversion. But most studies of crime from an economic perspective focus on men only. This is a severe shortcoming for understanding women in crime because there are bound to be many differences between men and women concerning what motivates their behavior, and these differences would imply that different policies are required to reduce the propensity to commit a crime. 
Unlike the dearth ofeconomic studies, there have been extensive investigations by sociologists, criminologists, and psychologists of the differences in criminal behavior between men and women. The early literature on this subject, starting with Cesare Lombroso and Sigmund Freud, claimed that female criminals were anomalies, and that they showed biological and psychological traits that were very similar to those of male criminals.

Later, criminologists and sociologists used other paradigms to explain female participation in crime, stressing the importance of socio-cultural factors and emphasizing that the role of gender in the crime market mirrors the role of gender in wider society. They argued that if the gender gap in crime was the result of biological differences between men and women it would not change over time or space, which it clearly does (Figures 1 and 2). A "gender equality hypothesis" emerged, arguing that the reduction in the gender gap in crime, along with its variation across (developed and developing) countries and urban and rural areas, was related to the reduction in gender gaps in other areas of life.

\section{Which crimes do women commit?}

Since statistics on women in crime have been long neglected, and stereotypes on the issue abound, it is important to look at reliable data that describe the phenomenon accurately.

The analysis presented in this article shows that women are increasingly active in the crime market (Figures 1 and 2). But what kinds of crimes do women commit? Analysis of US arrest data over 1980-2011 for two large categories of crimes-property crimes and violent crimes-shows that women commit twice as many property crimes as violent crimes (Figure 3). Over time, however, the proportion of women arrested for property crimes has increased more slowly (by 77\% since 1980) than the proportion arrested for violent crimes (by 96\%).

Figure 3. Twice as many women were arrested for property crimes as for violent crimes in (the US from 1980 to 2011

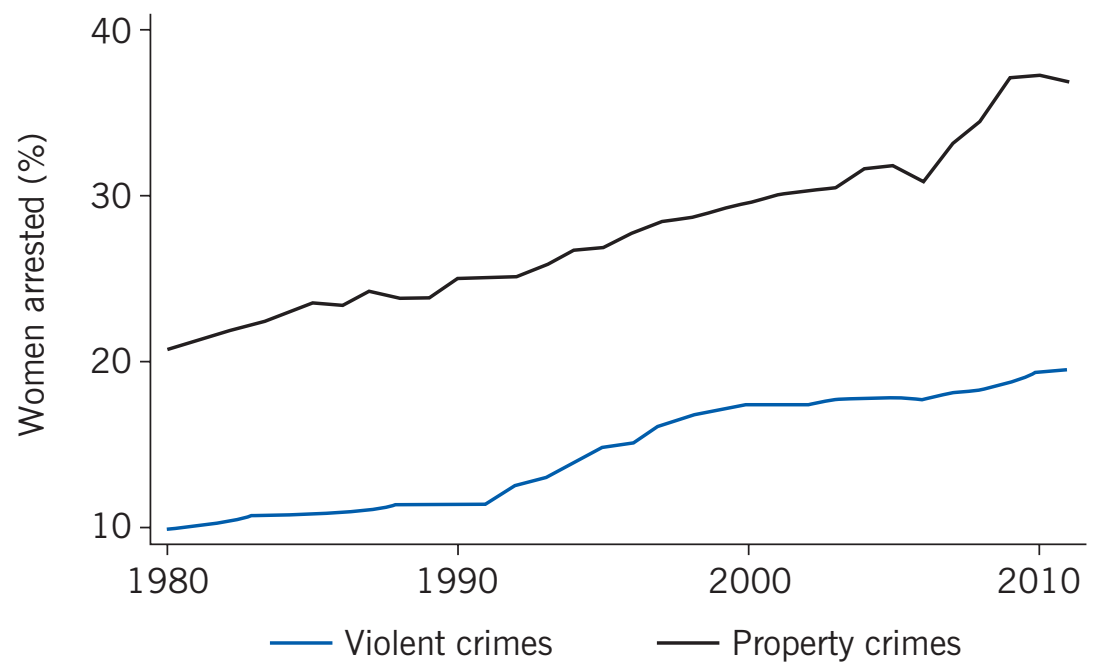

Source: Bureau of Justice Statistics. Online at: http://www.bjs.gov 
A more detailed breakdown of evidence on the types of crimes committed by men and women in 2009 in the US, England and Wales, and Italy using data on men and women in prison shows that women, on average, tend to commit mostly property crimes, in particular theft, fraud, and drug offences (Figure 4) [2].

Figure 4. In the US, England and Wales, and Italy, women tend to commit mostly property Crimes, 2009

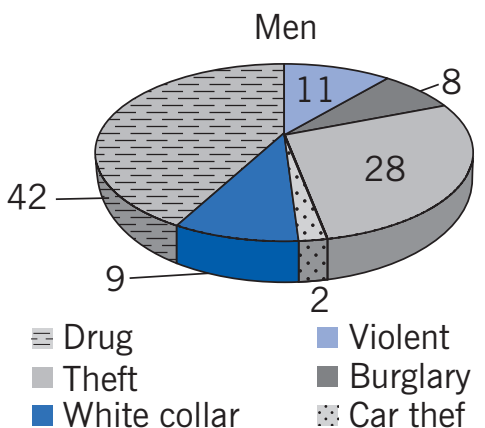

US
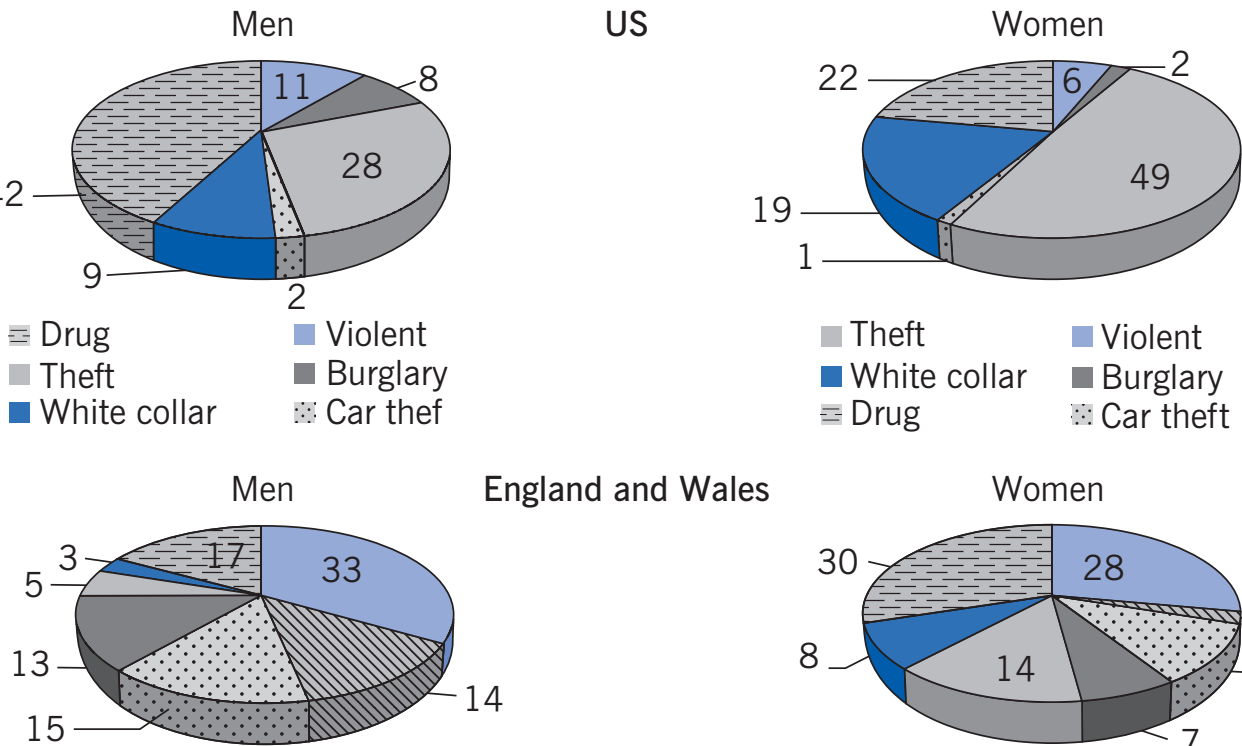

England and Wales

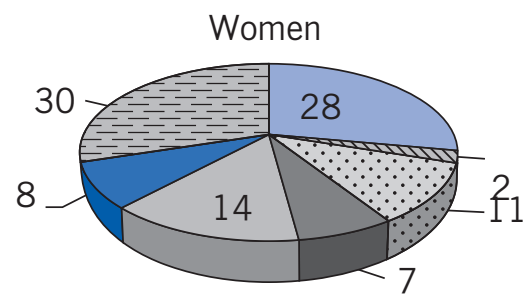

Violence against the person

= Drug

$\therefore$ Robbery

N Sexual offences

- Burglary

Theft and handling

- Fraud and forgery

$$
\equiv \text { Drug }
$$

Violence against the person

Theft and handling

$\therefore$ Robbery

Fraud and forgery

Burglary

N Sexual offences

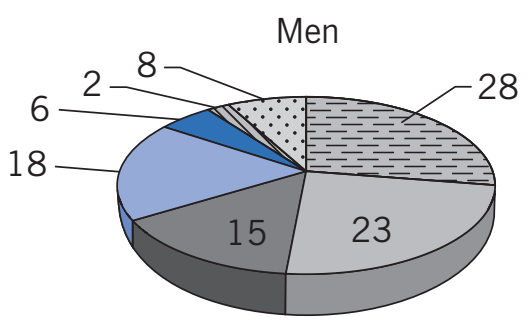

Italy

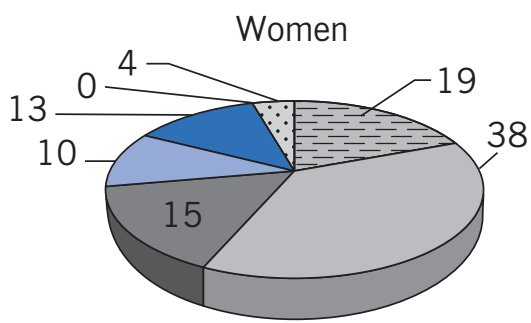

= Drug

Theft and handling

- Violence against the person

- Undocumented immigration

Fraud

$\therefore$ Robbery

N Sexual offences

- Theft and handling

E Drug

Undocumented immigration

- Fraud

Violence against the person

$\therefore$ Robbery

N Sexual offences

Source: Sandler, D. H., and J. Schaller. Female Crime in the Long and Short Run. US Census Bureau Working Paper, May 23, 2012. Online at: http://www.dhsandler.com/uploads/3/0/2/8/3028537/female_crime_50712.pdf [2]; UK Ministry of Justice. "Women and the criminal justice system." Online at: https://www.gov.uk/government/statistics/ women-and-the-criminal-justice-system--2; ISTAT (Italian National Statistics Bureau). "I condannati con sentenza definitiva nel periodo 2000-2011. Tavola 4: Principali reati con sentenza irrevocabile per sesso del condannato e anno di iscrizione-Anni 2000-2011 (valori assoluti)" ["Convicted by final judgment over the period 2000-2011. Table 4: Main crimes with final judgment by gender and year of arrest-Years 2000-2011 (absolute values)"]. Online at: http://www.istat.it/it/archivio/103655 
In the US, both men and women engage mostly in crimes against property, including burglary, theft, car theft, and white-collar crimes. Property crimes represent almost $70 \%$ of total crimes for women and around $50 \%$ for men who are in prison. The share of drug crimes and violent crimes is almost twice as high among men as among women.

In England and Wales, crimes against the person and drug offences are the most common crimes for both men and women. Gender gaps in the types of crimes committed by people who have been imprisoned for their crimes are greatest for drug offences $(30 \%$ of the crimes committed by women and $17 \%$ of the crimes committed by men), theft and handling stolen goods ( $14 \%$ for women and $5 \%$ for men), fraud and forgery ( $8 \%$ for women and $3 \%$ for men), and sexual offences ( $2 \%$ for women and $17 \%$ for men).

In Italy, as in England and Wales, drug offences and theft and handling stolen goods are the most common crimes for all people imprisoned for a crime. Women tend to commit more theft ( $38 \%$ of the crimes committed by women and $23 \%$ of the crimes committed by men) and fraud (13\% for women and $6 \%$ for men), while men commit more robberies ( $8 \%$ for men and $4 \%$ for women) and violence against persons ( $18 \%$ for men and $10 \%$ for women).

\section{Why do women commit fewer crimes, and why are gender differences shrinking?}

Studies have analyzed the factors that might explain these differences in criminal propensity between men and women and have examined whether these factors show any convergence over time (potentially contributing to the convergence in crime rates between men and women).

\section{The role of incentives}

The gender variation in crime might be explained by differences in incentives facing women and men in committing a crime. Incentives, in turn, determine the benefits and the costs of engaging in illegal activity.

A recent study focusing on property crimes investigates whether there is a gender difference in the probability of arrest (one of the costs of engaging in crime) and in illegal earnings (one of the benefits of engaging in crime) that might explain the difference in crime propensity [3]. Using a large administrative data set for the US (the National Incident-Based Reporting System Resource) with data on individuals from 1995 to 2015, the study finds that there is a gender difference in incentives to participate in criminal activities: on average, men earn $13 \%$ more than women and face a $9 \%$ higher probability of arrest. There are a number of potential explanations for this: ability, choices, effort, search costs, as well as underlying risk aversion. The same study investigates whether female and male crime rates respond differently to changes in expected incentives to commit crimes. Males are more responsive to changes in illegal earnings (doubling expected illegal earnings increases the crime rates of men by $36 \%$ and of women by $23 \%$ ) while there is no gender difference in responsiveness to changes in probability of arrest (doubling the expected probability of arrest decreases crime rates by $14 \%$ for both women and men).

These findings partly explain why there are fewer women than men in the crime market: differences in incentives explain about $8 \%$ of the gender participation gap, while differences in responsiveness to changes in incentives explain $56 \%$ of the gap. 
A related issue is the gender gap in incarceration. Women commit around $30 \%$ of property crimes in the US but represent less than $10 \%$ of the prison population [3]. One potential reason for the gap is that, all else being equal, women accused of a crime are treated more leniently by the justice system than men who are accused of a crime. This more lenient treatment tends to lower the expected cost of committing a crime for women.

A study examining whether there are significant differences in sentencing in the US between individuals sentenced in the same district courts who committed the same type of crime and have the same criminal history finds that women receive shorter sentences than men, are less likely to have their sentences adjusted upward, and are more likely to receive no prison term [4]. Judges and police officials tend to be more lenient with female criminals, conferring an advantage on women in terms of the expected costs of a criminal act.

Since there are no empirical studies on the "chivalry theory" that use non-US data, UN crime data for the same countries as in Figure 2 (i.e. Italy, Germany, Greece, Japan, Norway, and the UK) were analyzed to compare the percentage of women suspected of crimes with the percentages prosecuted, convicted, and incarcerated. The analysis shows that as a percentage of all men and women in each category, the percentage of women prosecuted is lower than the percentage of women suspected, the percentage of women convicted is lower than the percentage of women prosecuted, and the percentage of women incarcerated is lower than the percentage of women convicted. These results suggest that female criminals are treated more leniently than male criminals not only in the US but also in many other countries (at least in Europe and Japan). Of course, this hypothesis requires deeper empirical investigation-for example, controlling for the type of crime committed and other important characteristics of the perpetrator.

\section{The role of education}

Gender convergence in crime over time might also be partly explained by a different effect, that of education. Empirical evidence using census data from 2001 to 2016 on young people (aged 15-21) in Queensland, Australia, shows that a 2006 reform which aimed to extend compulsory education negatively affected crime rates (especially property crimes) but with a magnitude for males that was more than double that for females, thus contributing to narrowing the gender gap in crime [5].

Another study that uses US data on white women from 1960 to1980 shows that an additional year of schooling reduces the probability of incarceration by $0.05-0.09$ percentage points and the female arrest rate by more than $50 \%$, for both violent and property crime, while there is little impact on white-collar crime [6]. Similar studies that observe men find that the effect of one more year of schooling on conviction is about four times higher for men than for women. Regarding arrests, an additional year of education reduces arrests by only $5-10 \%$.

Differences in the mechanisms that drive the effect of education on crime across gender might explain differences in the magnitude of the effect. For men, education increases labor market opportunities and wages, while for women education has historically increased opportunities in the marriage market, thus potentially improving social networks, generating stronger social bonds, and acting as a stricter informal social control [7]. Furthermore, over the period 19601980, more educated women tended to have more children, which represent an opportunity cost for them when considering committing a crime. In more recent years this trend may have changed, however, as better-educated women are more present in the labor market, spend less time at home, and have fewer children [6]. 


\section{The role of labor market opportunities}

In the 1970s, it became clear that female criminality had been rising in the US for property crimes but not for violent crimes such as homicide or robbery. One theory was based on opportunism: the dramatic increase in property crime was the result of more women entering the labor market and finding themselves in positions that allow them to commit such offenses [8]. An empirical investigation in 1970 corroborated this theory, finding that employed women tend to commit more crimes than women who are not in the labor force [9]. Another study finds similar results using a search model that comprises the option to commit crimes and comparing female labor force participation rates and crime rates in 1960 and 2005 [10].

However, a more recent study finds contrasting results, showing that a legal job seems to be a substitute for an illegal one. It measures the effect of the US welfare reform legislation of the 1990s on crime, aimed at incentivizing work among women at risk of relying on public assistance [11]. The study finds a $4.4-4.9 \%$ decrease in property crimes committed by women and no effect on violent crimes.

Some researchers argue for another potential mechanism, not yet tested, that might lead to an increase in female crime [10]. They contend that it is important to look not only at the absolute gender wage gap (the average hourly earnings for a female worker amounted to about $80 \%$ of the average for a male worker in the US in 2000 compared with about $60 \%$ in 1960) but also at relative inequality in the distribution of wages for men and women, which shows that wage disparity across skilled and unskilled jobs is greater for women than for men. Skilled workers tend to commit fewer crimes than unskilled workers because their relative wage is increasing over time thanks to skillfavoring technological change. Since high-value crimes are less frequent than low-value crimes and relative wage inequality has increased more for women than for men, it is not surprising that the number of crimes committed by women (compared to men) has increased in recent decades.

\section{The role of marriage, child rearing, and household tasks}

For women, the decision to engage in criminal activity cannot be explained simply in terms of opportunity cost in the legal market. Child rearing and housekeeping play a potentially more important role for women than they do for men [12].

Over the years, technological progress and social norms have reduced the value of housekeeping. For example, the share of US households with a dishwasher rose from $42 \%$ in 1985 to $63 \%$ in 2009 , and the share of those with a washing machine rose from $67 \%$ to $77 \%$ [2]. These differences would be even more striking if there were data back to the post-Second World War period. Also changing the marginal value of time spent at home is the rise in childcare assistance. The share of children under the age of five cared for by a non-relative rose from $39.3 \%$ in 1977 to $52.2 \%$ in 2009 . As a consequence, the opportunity cost of participating in illegal activities is smaller than in the past, implying that women might have a higher propensity to commit crime [10].

Furthermore, it is important to stress that illegal activities are not necessarily substitutes for legal activities and for time spent on household tasks. For example, a person might do the shopping for the household and, at the same time, decide to shoplift, or a person with a job could decide to commit white-collar crimes at work. This is exactly what a 1979 empirical study found: married women are more likely to commit larceny (shoplifting), 
while no effect is found for personal crimes and other property crimes that require more experience and skills, such as auto theft, burglary, and robbery [9].

The same study stresses that marital status might have an important role in the decision to commit crime [9]. Unmarried women tend to have a more regular work history than married women do, with the result that unmarried women and their employers tend to invest more in human capital. That gives unmarried women greater opportunities for legal work over their lifetime than married women. On the one hand, if the crime market requires fewer skills than the job market, one should expect to find more married women involved in criminal activities. Again, on the other hand, married women are more likely to have children and to be able to insure against negative income shocks because of their husbands' incomes. These elements should drive expectations in the opposite direction. Married women who are not in the labor force tend to commit more property crimes than unmarried women, but not more violent crimes. And women in the labor force are not more prone to commit property crimes if they are single. Furthermore, for married women, the number of preschool children they have has a negative impact on crime participation, probably because children increase a mother's disutility in going to jail.

\section{Gender discrimination in the crime market}

A 2019 study using US data on property crimes looks at whether women are discriminated against not only in the legal job market but also in the crime market and finds discriminatory bias in male and female partnering to commit a crime. A man decides to partner with a woman to commit a crime only if the woman is more productive (measured in terms of ability to escape law enforcement) than he is [13]. The assumption is that a criminal has an incentive to pair with someone who faces the lowest probability of being arrested because police generally offer a bargain to the criminal who is caught first in order to catch the partner.

Discriminatory bias in partnership formation to commit a crime is thus another element that might partly explain the gender gap in the crime market. It could be that the reduction in the gender bias in other dimensions might lead to a reduction in the gender bias in the crime market, thus increasing the number of women involved in criminal activity.

\section{LIMITATIONS AND GAPS}

There are just a few empirical studies that have investigated the reasons behind the increase in the proportion of women in crime over the last 50 years and that have tried to identify the determinants of the narrowing of the gender gap in criminal participation. Since the pioneering 1979 study [9], socio-economic conditions have changed considerably. The increase in female participation in the labor market, the declines in marriages and childbearing, the advances in technology, and the strong shifts in social norms (e.g. it is no longer unusual for a woman to be the breadwinner in a family) have probably changed the determinants of female criminal behavior since the 1970s.

Furthermore, the availability of new data (especially at the individual level) and more precise methods for analyzing them suggest that new research is needed.

\section{SUMMARY AND POLICY ADVICE}

Gender gaps in the labor market have been narrowing over time, and research has devoted considerable attention to this phenomenon. A similar pattern has been observed in the 
crime gap, but much less research has been devoted to explaining this phenomenon. Thus, less is known about gender gaps in crime, other than that very few women commit crimes. Economic, social, and cultural factors likely contribute to this crime gap. Women have been shown to participate less in the crime market than men because they face different benefits and costs from committing crimes. For example, they face different incentives: the amount of criminal earnings is higher for men and therefore women face lower incentives to engage in crime. Furthermore, women who have very young children have a higher disutility in going to jail. All these factors might, at least in part, explain why there is a gender gap in the crime market.

One potential reason for the rising number of female criminals is that changes in social roles and technological progress have freed women from the home and reduced the marginal value of housekeeping. As for female employment and wages, their effect on female crime is ambiguous. One theory, not yet tested, is that relative wage inequality is important, not just the wage gap alone. Over the last decades, relative wage inequality has been increasing more for women than for men, which might have pushed more women at the low end of the wage distribution to commit crimes. Differences in the magnitude of the effect of education on crime have also contributed to shrink the gender gap in crime participation. Finally, the judicial system is more lenient with women than with men, thus giving women an advantage in the crime market.

These findings suggest that policymakers should take into account the possibility that positive changes that narrow gender gaps in the labor market and positive changes in social roles might have induced more women to participate in crime. Policies that help reduce wage disparity across skilled and unskilled female workers, such as incentivizing female education, might deter disadvantaged women from engaging in criminal activities. Finally, lower rates of marriage and childbearing may also be pushing more women into crime, so family support policies that encourage marriage and childbearing might also reduce female criminal activity.

\section{Acknowledgments}

The author thanks two anonymous referees and the IZA World of Labor editors for many helpful suggestions on earlier drafts. Version 2 of the article updates Figure 1, expands the discussion on the role of incentives, explores the role of education, and adds "Key references" [5], [6], [7].

\section{Competing interests}

The IZA World of Labor project is committed to the Code of Conduct. The author declares to have observed the principles outlined in the code.

(C) Nadia Campaniello 


\section{REFERENCES}

\section{Further reading}

Alarid, L. F., V. S. Burton, F. T. Cullen, S. J. Cuvelier, and J. W. Marquart. "Women's roles in serious offenses: A study of adult felons." Justice Quarterly 13:3 (1996): 431-454.

Cook, S., D. Watson, and L. Parker. "New evidence on the importance of gender and asymmetry in the crime-unemployment relationship." Applied Economics 46:2 (2014): 119-126.

\section{Key references}

[1] Becker, G. S. "Crime and punishment: An economic approach." Journal of Political Economy 76:2 (1968): 169-217.

[2] Sandler, D. H., and J. Schaller. Female Crime in the Long and Short Run. US Census Bureau Working Paper, 2012.

[3] Campaniello, N., and E. Gavrilova. "Uncovering the gender participation gap in crime." European Economic Review 109 (2018): 289-304.

[4] Mustard, D. B. "Racial, ethnic and gender disparities in sentencing: Evidence from the U.S. federal courts." Journal of Law and Economics 44:1 (2001): 285-314.

[5] Beatton, T., M. P. Kidd, and S. Machin. "Gender crime convergence over twenty years: Evidence from Australia.” European Economic Review 109 (2018): 275-288.

[6] Cano Urbina, J., and L. Lochner. "The effect of education and school quality on female crime." Journal of Human Capital (Forthcoming).

[7] Lochner L., and E. Moretti. "The effect of education on crime: Evidence from prison inmates, arrests, and self-reports." American Economic Review 94:1 (2004): 155-189.

[8] Simon, R. J. "American women and crime." Annals of the American Academy of Political and Social Science 423:1 (1976): 31-46.

[9] Bartel, A. P. "Women and crime: An economic analysis." Economic Inquiry 17:1 (1979): 29-51.

[10] Engelhardt, B., G. Rocheteau, and P. Rupert. "Crime and the labor market: A search model with optimal contracts.” Journal of Public Economics 92:10 (2008): 1876-1891.

[11] Corman, H., D. M. Dave, and N. E. Reichman. "Effects of welfare reform on women's crime." International Review of Law and Economics 40 (2014): 1-14.

[12] Freeman, R. B. "The economics of crime." In: Ashenfelter, O., and D. Carr (eds). Handbook of Labor Economics. Amsterdam: Elsevier, 1999.

[13] Gavrilova, E. "A partner in crime: Assortative matching and bias in the crime market." Journal of Economic Behavior and Organization 159 (2019): 598-612.

\section{Online extras}

The full reference list for this article is available from:

https://wol.iza.org/articles/women-in-crime

View the evidence map for this article:

https://wol.iza.org/articles/women-in-crime/map 